\title{
Effects of initial functional-group composition on assembly trajectory in savanna restoration
}

\author{
André Ganem Coutinho $^{1}$ | Monique Alves $^{1}$ | Alexandre Bonesso Sampaio ${ }^{2}$ | \\ Isabel Belloni Schmidt ${ }^{3}$ (D) | Daniel Luis Mascia Vieira ${ }^{4}$
}

${ }^{1}$ Pós Graduação em Ecologia, Universidade de Brasília, Brasília, Brazil

${ }^{2}$ Centro Nacional de Pesquisa e Conservação da Biodiversidade do Cerrado e Caatinga, Instituto Chico Mendes de Conservação da Biodiversidade, Brasília, Brazil

${ }^{3}$ Departamento de Ecologia, Universidade de Brasília, Brasília, Brazil

${ }^{4}$ Laboratório de Ecologia e

Conservação, Embrapa Recursos Genéticos

e Biotecnologia, Brasília, Brazil

\section{Correspondence}

Daniel Luis Mascia Vieira, Laboratório de Ecologia e Conservação, Embrapa Recursos Genéticos e Biotecnologia, Brasília, Brazil. Email: daniel.vieira@embrapa.br

\section{Funding information}

This research was financed by Fundação Grupo Boticário de Proteção à Natureza, intermediated by PEQUI - Pesquisa e Conservação do Cerrado.

Co-ordinating Editor: David Ward

\begin{abstract}
Aims: Indicators that can provide information during the early stages of restoration are very useful for predicting restoration outcomes. We posed the following questions: Can savanna restoration outcomes be affected by the initial functional-group composition? Are there functional groups that, when established early, can prevent colonization by invasive grasses, trigger a successful restoration trajectory, and be used as early indicators of restoration success?

Location: Brazilian savanna (cerrado) in Central Brazil $\left(14^{\circ} 07^{\prime} 2.54^{\prime \prime} \mathrm{S}\right.$,

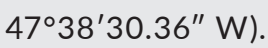

Methods: We established 110 plots spanning a naturally occurring range of species composition in savanna areas that had been restored through direct seeding. We looked for different initial compositions of the following functional groups: perennial grasses, annual grasses, short-lived shrubs, and invasive grasses. We measured vegetation cover over two years and evaluated the effects of the initial functional composition on the successional trajectory of the plots.

Results: The initial dominant functional group determined the assembly trajectory. Short-lived and fast-growing species were replaced by perennial species, indicating a fast species turnover. Invasive grass cover remained stable over time, demonstrating that once they establish and dominate an area, an alternative stable state is achieved. Conclusions: Our results demonstrate the importance of introducing a mixture of functional groups when restoring savannas in severely disturbed areas. Fast-growing and short-lived species are important for quickly covering the ground, creating the conditions for the establishment of perennial grasses that naturally dominate the herbaceous layer of savannas. Trees are also characteristic of the savanna structure and must be introduced. Our results indicate that invasive grasses must be eliminated and/or constantly controlled before native species are introduced.
\end{abstract}

\section{KEYWORDS}

assembly trajectory, cerrado, direct seeding, functional group, invasive grasses, priority effects, savanna restoration, species turnover, succession 


\section{1 | INTRODUCTION}

Understanding the assembly triggers and trajectories of ecosystems under restoration is essential to improving restoration methods (Suding \& Hobbs, 2009). Achieving restoration goals may require implementing different management steps to steer ecosystems into desired assembly trajectories. This may involve restoring the physical and chemical conditions of the soil, controlling invasive species and introducing different functional groups to recreate successional stages, thus reconstructing community structure and biodiversity (Clewell \& Aronson, 2007). There is a growing consensus that community assembly is not deterministic and may follow different trajectories determined by historic events and biotic, abiotic and seed dispersal filters (Fukami, 2015; Young, Zefferman, Vaughn, \& Fick 2014). Therefore, understanding community assembly pathways allows us to assess what determines success or failure and to develop adaptive management practices.

There is still limited knowledge on savanna trajectories after disturbances. Most savanna succession studies focus on determinants of coexistence between trees and grasses. Soil conditions, rainfall seasonality (Lehmann, Archibald, Hoffmann, \& Bond, 2011) and frequency and intensity of disturbances, especially fire (Bond \& Keeley, 2005; Hoffmann et al., 2012) and grazing (Jacobs, Kingston, \& Jacobs, 1999), are important structuring factors in savannas. Savanna species evolved with these disturbances and often have adaptations to protect regenerative tissues, such as large belowground organs and thick barks (Lawes, Adie, Russell-Smith, Murphy, \& Midgley, 2011; Simon et al., 2009) that enable surviving and resprouting after disturbance (Souchie et al., 2017). However, major anthropogenic disturbances, such as intensive farming, pastures and mining, decrease plant resprouting ability (Ferreira, Walter, \& Vieira, 2015). Most savanna successional models do not take into account situations in which the bud and seed banks have been depleted (Veldman et al., 2015). In addition, the autecology of tropical savanna species and the vegetation dynamics of its herbaceous layer are still poorly understood, and assembly and succession models need to be expanded to include disturbances that eliminate resprouting ability (Cava, Pilon, Ribeiro, \& Durigan, 2017).

Savanna restoration faces several challenges. First, natural regeneration tends to be slow, since most species are adapted to persist, rather than disperse (Bond \& Parr, 2010). As a result, restoring severely disturbed savanna sites requires active restoration. Direct seeding, hay transfer and topsoil transfer are considered effective methods for grassland restoration (Ferreira et al., 2015; Hedberg \& Kotowski, 2010; Pilon, Buisson, \& Durigan, 2017). There are few studies on savanna restoration, but direct seeding is the most commonly used technique (Palma \& Laurance, 2015) and has been successfully used to establish native species in Brazilian savannas (Pellizzaro et al., 2017; Silva \& Vieira, 2017). The advantages of this method include low cost and easy implementation (Grossnickle \& Ivetić, 2017; Palma \& Laurance, 2015). Seeds may be introduced at high densities (Campos-Filho, Da
Costa, De Sousa, \& Junqueira, 2013), a requirement for adequately covering the ground with grasses and herbs that is cost-prohibitive with seedling planting (Grossnickle \& Ivetić, 2017). Moreover, direct seeding may impose a lighter anthropogenic fingerprint, since the resulting community is naturally selected from the large density of individuals initially sown.

Invasive grass species are another major hurdle for the restoration of grassy biomes around the world. Both in Neotropical and in Australian savannas, African grasses were introduced for pasture enhancement and intentionally dispersed to a wide range of areas (Foxcroft, Richardson, Rejmánek, \& Pyšek, 2010; Parsons, 1972). These species evolved with fire and intense herbivory by large mammals, becoming well adapted to grazing, whereas native species of Neotropical and Australian savannas are less tolerant of defoliation (Baruch, 1996). Fast biomass accumulation increases fire frequency and intensity, creating grass-fire cycles that favor invasions (D'Antonio \& Vitousek, 1992). These adaptations are related to functional traits; African grasses have high growth rates, which enable them to establish quickly and successfully compete for resources (Baruch, Hernandez, \& Montilla, 1989). Invasive species have higher phenotypic plasticity when there is no resource limitation (Davidson, Jennions, \& Nicotra, 2011), increasing their adaptability to different conditions. These traits allow invasive grasses to displace native grasses, leading to alternative stable states dominated by the invasive grasses (Almeida-Neto et al., 2010; Firn, House, \& Buckley, 2010; Pivello, Shida, \& Meirelles, 1999; Veldman et al., 2015).

The competition between native and invasive species at the beginning of community assembly can have both short and long-term effects on restoration (Vaughn \& Young, 2015; Werner, Vaughn, Stuble, Wolf, \& Young, 2016) and it is influenced by the functional traits of the introduced species (Almeida-Neto et al., 2010; Fort, Cruz, \& Jouany, 2014; Funk, Cleland, Suding, \& Zavaleta, 2008; Kunstler et al., 2016; Pywell et al., 2003). Thus, initial functionalgroup composition may influence the success or failure of restoration efforts. Monitoring restoration trajectories arising from different initial functional-group compositions identifies groups that are able to promote successful restoration (González, Rochefort, Boudreau, Hugron, \& Poulin, 2013; Suding, 2011; Wortley, Hero, \& Howes, 2013), and finding indicators of restoration success at the early stages of regeneration is useful to predict restoration outcomes (González et al., 2013).

We tracked savanna community assembly in $1 \mathrm{~m}^{2}$ plots, a size that corresponds to the area within which plants interact, as part of a large-scale savanna restoration project in abandoned pastures in central Brazil. Invasive grasses recolonized the areas being restored, germinating from the seed bank and creating patches with different proportions of native species and invasive grasses. Over a period of two years, we monitored areas that were dominated initially by different functional groups (native annual grasses, native perennial grasses, native short-lived and fast-growing shrubs, native fast-growing trees, and invasive grasses) to answer the following questions: (1) Are the final (after two years) species composition and 
FIGURE 1 Savanna restoration sites in Chapada dos Veadeiros National Park, central Brazil. Points indicate each of the $1101-m^{2}$ permanent sampling plots. The map on the top right shows the location of the restoration area in Brazil [Color figure can be viewed at wileyonlinelibrary.com]

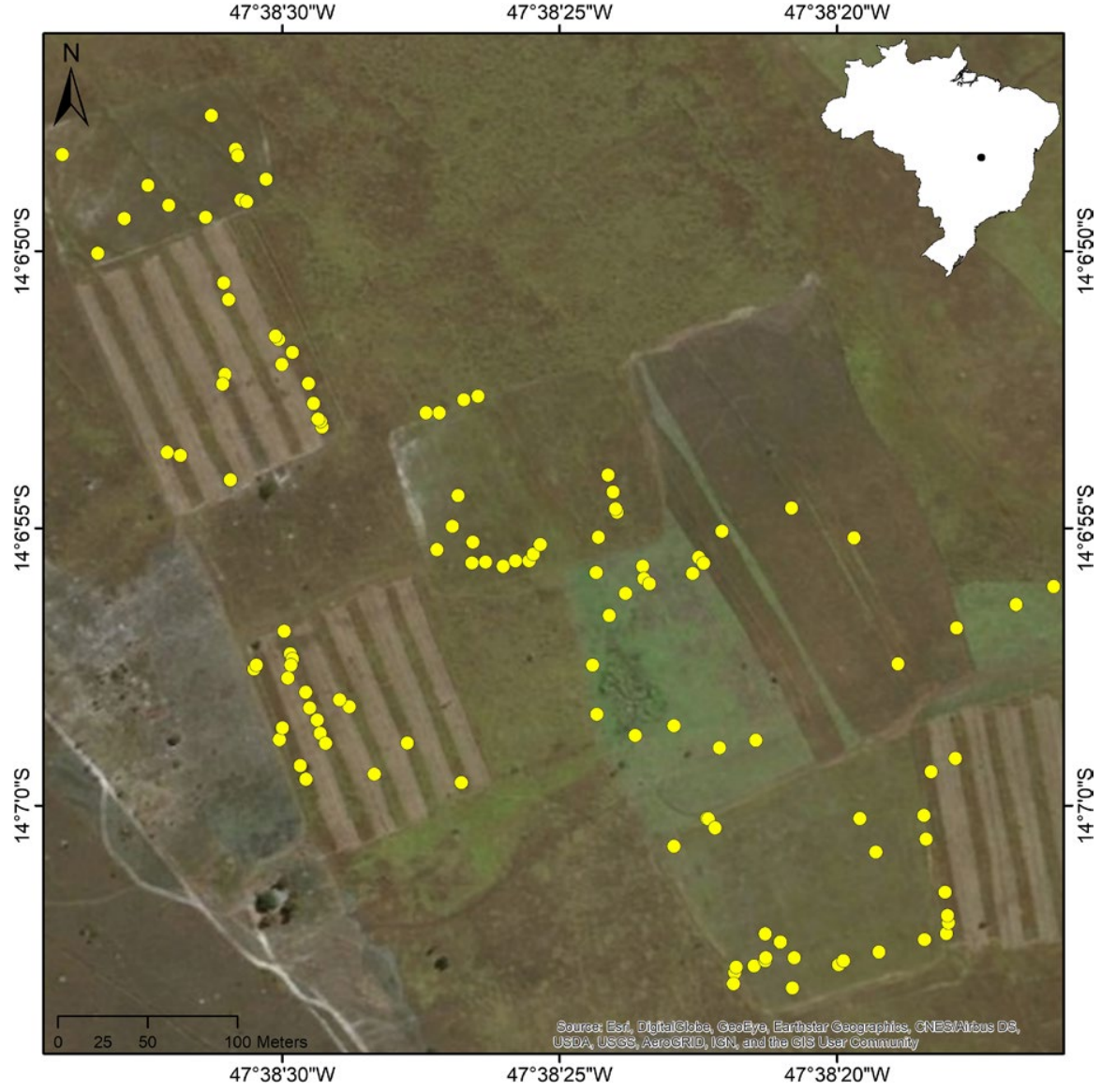

final proportions of native and exotic species determined by (a) initial composition, (b) initial proportion of native species, or (c) initial dominant functional group?; and (2) Do restoration sites exhibit species turnover, indicating a successional trajectory?

\section{2 | METHODS}

\subsection{Study site}

The study was conducted in Chapada dos Veadeiros National Park, central Brazil $\left(14^{\circ} 07^{\prime} 2.54^{\prime \prime} \mathrm{S} 47^{\circ} 38^{\prime} 30.36^{\prime \prime} \mathrm{W}\right)$, between 800 and $1,650 \mathrm{~m}$ above sea level. Annual precipitation ranges from 1,500 to $1,750 \mathrm{~mm}$, concentrated between October and April (Aw climate in Köppen's classification (ICMBio, 2009)). The study area is located on a flat terrain with a prevalence of Plinthosols.

Based on the surrounding vegetation and soil conditions, the original vegetation cover of the study site was open savanna, a vegetation type comprised of an herbaceous layer with 5\%-20\% of tree and shrub cover (Ribeiro \& Walter, 2008). The area was converted into pasture before the 1980s and left abandoned for at least 20 years, with no cattle grazing or management. The area was dominated by invasive grasses when a restoration program was initiated in 2012.

In each of the 2012, 2013, and 2014 sowing campaigns a new adjacent area was selected for direct seeding of native grasses, shrubs and trees (Figure 1; see the species list inAppendix S1). Each sowing campaign was part of a large-scale experiment ( $\geq 3 \mathrm{ha}$ ) within the context of an adaptive management model (A. B. Sampaio, I. B. Schmidt, D. L. M. Vieira, K. D. Holl, K. F. Pellizzaro, M. Alves, A. G. Coutinho, \& A. O. O. Cordeiro, in preparation), meaning that the number and type of soil preparation interventions and seed density and composition varied between years. In all sowing campaigns, the soil was prepared by repeatedly harrowing, decompacting the soil, uprooting invasive grasses and killing invasive grass seedlings that had germinated from the soil seed bank. In 2014, a controlled burn was conducted before soil harrowing to reduce the biomass of invasive grasses, facilitating harrowing and removal of invasive grass seeds above the soil surface. Because harrowing and fire do not eliminate the seed bank, invasive grasses have been able to reestablish in variable numbers.

Changes in seed density, species composition, micro-scale soil variation, and intensity and type of soil interventions between sowing campaigns created different conditions that led to the dominance of different functional groups. In 2015 there were patches dominated by invasive grasses, others dominated by native grasses, and others dominated by shrubs and trees. We also observed patches with intermediate proportions of these groups (Figure 2). Our goal was to understand the trajectories of species and functional groups over two years (2015-2017), in the period following the early establishment of the plants in these patches. It 


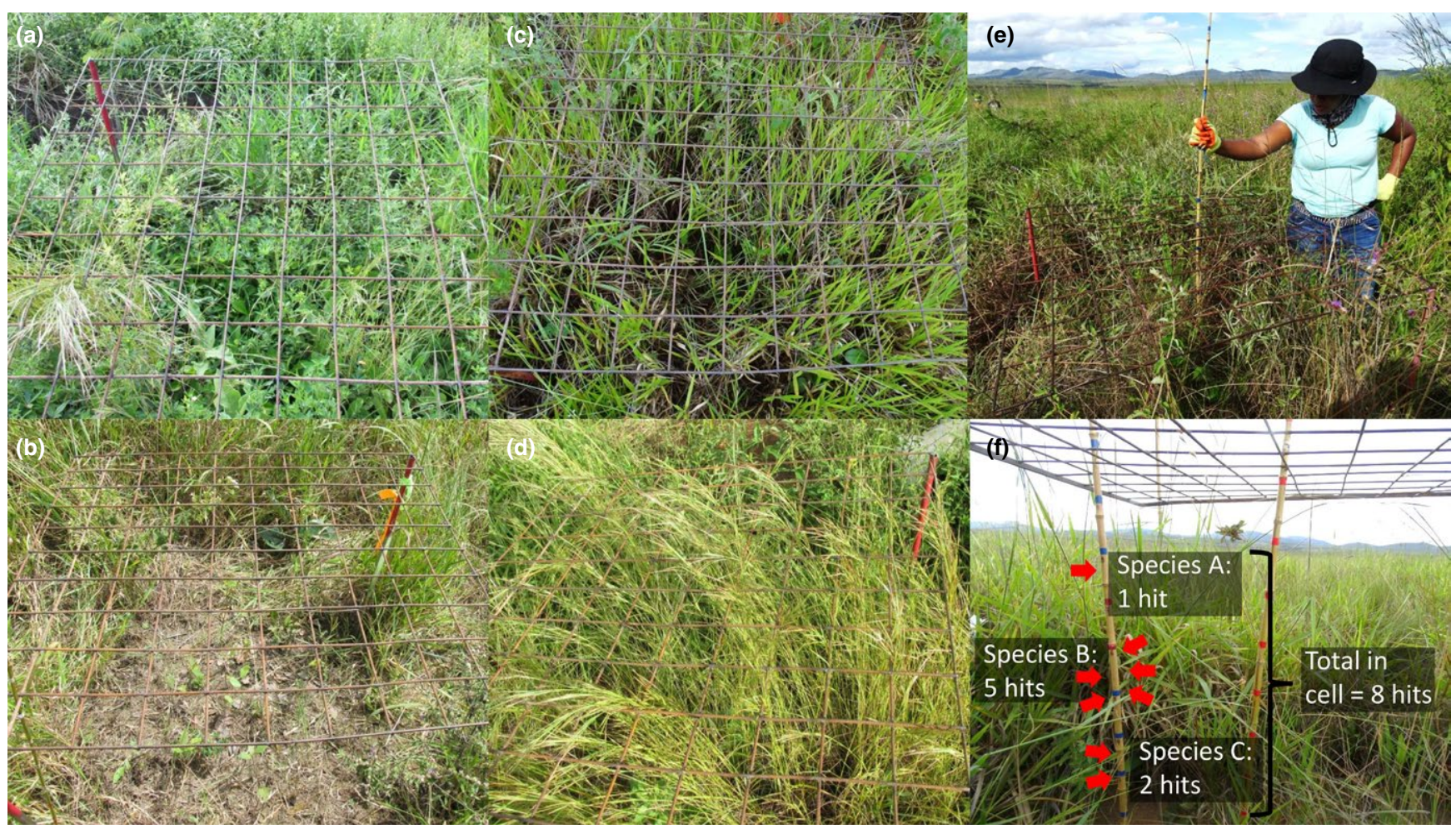

FIGURE 2 Examples of dominance and coexistence of different functional groups in study plots in savanna restoration sites in Chapada dos Veadeiros National Park, central Brazil. (a) Plot with no dominance (coexistence of native shrubs and grasses); (b) plot with low vegetation cover; (c) plot with dominance of the invasive grass Urochloa decumbens; (d) Plot with dominance of the native annual grass Andropogon fastigiatus; (e) and (f) steps for data collection: a stick is placed inside each grid cell; the observer counts the number of contacts by each species. More than one hit may be recorded per cell, meaning that total vegetation cover may exceed 100 for a single plot [Color figure can be viewed at wileyonlinelibrary.com]

is important to note that quantifying the effect of environmental and management variables in creating different patches was not the goal of our study.

\subsection{Experimental design and data collection}

In January 2015, $901 \times 1 \mathrm{~m}$ plots were established in restoration areas that had been seeded from 2012 to 2014 . We visually searched for the most pronounced gradient of functional-group composition, placing plots in areas with different proportions of native grasses, native shrubs, native trees and invasive grasses (Figure 2). The plots were not manipulated; as a result, plots could also have different biomasses and ages (between one and three years old). In April of the same year, we established 21 additional plots where all invasive grasses were removed (excavated) to increase the number of plots dominated by native species, for a grand total of 110 plots. Native species were not damaged. Plots were not manipulated again until the end of the study.

We measured vegetation cover at the species level, with the exception of Aristida spp. and Stylosanthes spp., which were measured at the genus level. Vegetation cover was repeatedly sampled in January and April (mid- and late-rainy season) of 2015 and 2017. We used the point-intercept method (Coulloudon et al., 1999; Jonasson, 1988), which generates an accurate three-dimensional representation of the space occupied by each species in each plot (vertical occupation and horizontal occupation), providing a good estimate of plant biomass (Jonasson, 1988). In each permanent plot, we used a $1 \mathrm{~m}^{2}$ iron frame subdivided into 100 square cells of $100 \mathrm{~cm}^{2}$. The frame was held horizontally $1.20 \mathrm{~m}$ above the ground. We inserted a 2-m long and 1-cm wide stick through each cell and recorded which species hit the stick and how many contacts each species made. We used "number of hits" as the unit of cover. Because cells did not have a limit on the number of hits, the total could easily exceed 100 hits in a single plot (Figure 2).

\section{3 | Statistical analysis}

We used exploratory plots to: (a) evaluate total vegetation cover in 2017 and shifts in the proportions of native and invasive grass species between 2015 and 2017; (b) assess competitive success in each plot based on shifts from the initial proportion; and (c) identify the best and worst performing species for each year in terms of total vegetation cover and shift in proportion between 2015 and 2017.

We grouped plots according to functional-group dominance. First, species were classified into functional groups based on origin (native or invasive), life form, life cycle and growth rate (see a list of the species and the corresponding functional group inAppendix S2). Plots were grouped based on dominance by functional 
TAB LE 1 Functional groups in 2015 and percentage cover of the two most dominant species in each group in savanna restoration sites in Chapada dos Veadeiros National Park, central Brazil

\begin{tabular}{lll} 
Functional group & Dominant species & $\begin{array}{l}\text { Percentage } \\
\text { cover (\%) }\end{array}$ \\
\hline Perennial grasses & S. sanguineum & 43.7 \\
& Aristida spp. & 16.6 \\
Short-lived shrubs & Stylosanthes spp. & 50.3 \\
& Lepidaploa aurea & 26.2 \\
Annual grasses & Andropogon fastigiatus & 71.7 \\
\multirow{2}{*}{ Invasive grasses } & Stylosanthes spp. & 10.4 \\
\multirow{2}{*}{ No dominance } & Urochloa decumbens & 33.8 \\
& Andropogon gayanus & 33.5 \\
Low vegetation & Andropogon gayanus & 17.0 \\
cover & Andropogon fastigiatus & 12.8 \\
Empty & Urochloa decumbens & 39.4 \\
& Stylosanthes spp. & 12.2 \\
& Andropogon gayanus & 21.0 \\
\hline
\end{tabular}

group or invasive species. We used the Berger--Parker dominance index (Berger \& Parker, 1970), a simple measure of the proportional importance of the most abundant species or functional group $\left(d=C_{\max } / C_{\text {tot }}\right.$, where $C_{\max }=$ cover of the dominant species and $C_{\text {tot }}=$ total plot cover). Plots with $d \geq 0.5$ were considered "dominated" and plots with $d<0.5$ were classified as "not dominated". In addition, plots with vegetation cover below 50 hits were considered "empty", and plots with 50-200 hits were classified as "low vegetation cover" (Table 1). All functional groups were dominated by one or two of the most important species (Table 1). For each plot, we determined the initial functional-group dominance and shifts in the dominance/cover category between 2015 and 2017. We used the Sankey diagram to show shifts in functional-group dominance between 2015 and 2017.

We used non-metric multidimensional scaling to analyze temporal variation in species composition. Rare species (occurrence $<5 \%$ ) were excluded from the analysis because they are less important for the dynamics studied, although they can influence the final result of assembly (Poos \& Jackson, 2012). This ordination was performed using the VEGAN package (Oksanen et al., 2018), in R software ( $R$ Core Team, 2017).

\section{3 | RESULTS}

In 2015 native species cover was $86 \%$ higher than invasive grass cover, but later invasive grasses doubled their cover, leading to similar cover values in 2017 (2015: invasive grasses $=1.32$ touches/ cell, on average; native species $=2.47$ touches/cell; 2017 : invasive grasses $=2.75$ touches $/$ cell; native species $=2.91$ touches $/$ cell).

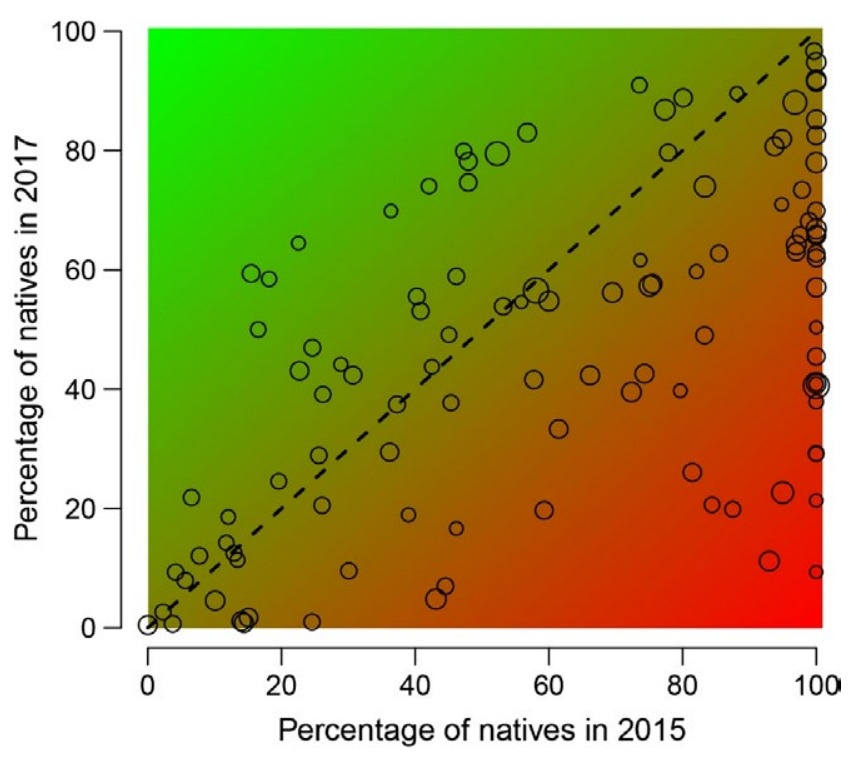

FIGURE 3 Dispersion plot of the native percent cover in 2015 (y-axis) and native percent cover in 2017 ( $x$-axis) in savanna restoration sites in Chapada dos Veadeiros National Park, central Brazil. The proportion of invasive grasses equals 100 minus the proportion of native species. Each point corresponds to one of the $1101-\mathrm{m}^{2}$ plots. Point size is proportional to total cover in 2015 (larger size = higher total plant cover). The dashed line separates plots where native percent cover increased (above the line) or decreased (below the line). The color corresponds to the intensity of variation; green means a shift from invasive grass to native species dominance and red means a shift from native species to invasive grass dominance [Color figure can be viewed at wileyonlinelibrary.com]

Invasive grass cover increased in 72 out of 110 plots, while native cover increased in 38 .

The proportional increase of native species cover (restoration success) or invasive grass cover (restoration failure) was not correlated with the initial proportions of native or invasive grass species (Figure 3). Only plots dominated by invasive grasses (above $80 \%$ ) remained stable. Plots with more than $20 \%$ of natives had both positive and negative variation in the percent cover of native versus invasive species (Figure 3).

There was considerable species turnover over two years. The short-lived shrubs Stylosanthes spp. and Lepidaploa aurea and the annual grass Andropogon fastigiatus had a high cover in 2015 that was strongly reduced by 2017 (Figure 4a). In contrast, the cover of the invasive grasses Urochloa decumbens and Andropogon gayanus, the native perennial grasses Schizachyrium sanguineum and Trachypogon spicatus and the fast-growing native tree Tachigali vulgaris increased over the same period (Figure 4a). The native grass Schizachyrium sanguineum and the invasive grasses Urochloa decumbens and Andropogon gayanus were the dominant species in 2015 and 2017 (Figure 4a). The NMDS revealed a compositional shift from short life-cycle species (short-lived shrubs and the annual grass Andropogon fastigiatus) to perennial species, both native and invasive (Figure 4b). Plots with native perennial grasses also tended to shift toward invasive grasses. 
(a)

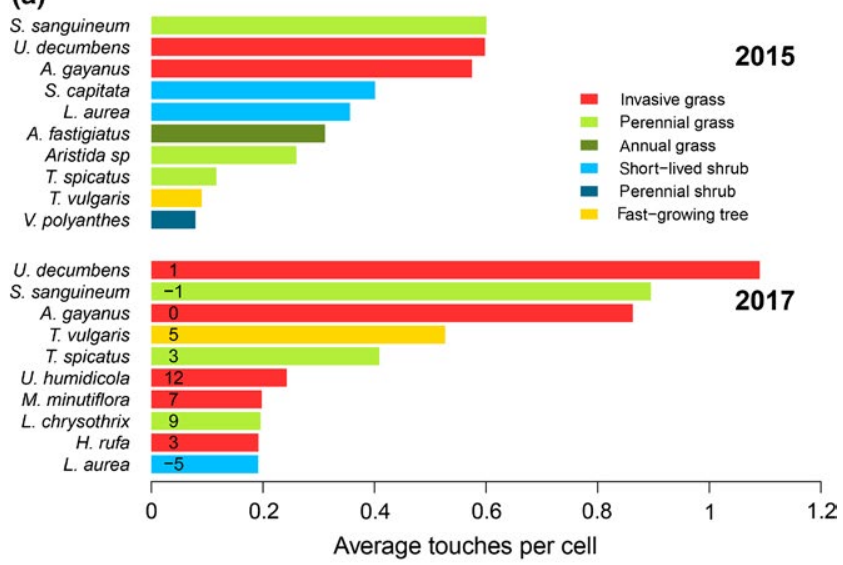

(b)

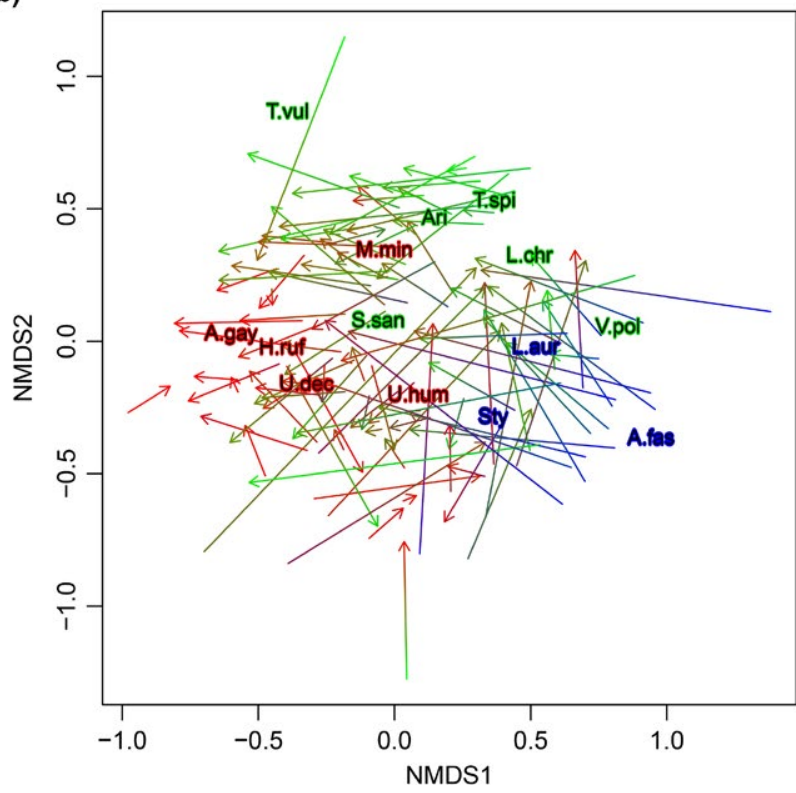

FIG URE 4 Vegetation dynamics at the species level in savanna restoration sites in Chapada dos Veadeiros National Park, central Brazil. (a) Top 10 species based on the mean number of touches per plot cell. For 2017 numbers above bars show the change in ranking position relative to 2015 . (b) NMDS showing compositional shifts of plant communities. Colors indicate the proportions of annual and short-lived natives (blue), other native species (green) and invasive grasses (red). "Other native species" includes perennial grasses, fast-growing trees, and average/slow-growing trees and shrubs. Only the scores of the top 10 species are shown, to facilitate the visualization of the temporal dynamics of the most relevant species [Color figure can be viewed at wileyonlinelibrary.com]

The plots became more heterogeneous in 2017, when 33 plots had no dominance compared to 17 plots in 2015 (Figure 5). Plots dominated by invasive species increased from 36 to 57 out of 110 plots. Forty-nine percent of the plots dominated by invasive species in 2017 had also been dominated by invasives in 2015, 19\% had had low coverage in 2015 and 32\% had been dominated by other functional groups or no dominance (Figure 5). However, six out of the 36 plots dominated by invasive grasses became no dominance plots. Perennial grasses were replaced by no dominance and invasive grass plots, but also maintained and reached dominance in plots of all groups, resulting in a decrease from 21 in 2015 to 15 in 2017 (Figure 5). Short-lived shrubs and annual grasses lost dominance primarily to invasive species, perennial grasses, or to the no dominance group (Figure 5). Most low-coverage plots shifted to invasive grass dominance (Figure 5).

\section{I DISCUSSION}

Attempts to reassemble grassy ecosystems through active restoration are recent and rare. Some examples are cerrado savannas in Brazil (Pellizzaro et al., 2017; Pilon et al., 2017; Silva, Oliveira, da Rocha, \& Vieira, 2015), semi-natural grasslands in Europe (Baasch, Engst, Schmiede, May, \& Tischew, 2016; Hedberg \& Kotowski, 2010), grasslands in USA (Holl et al., 2014; Martin, Moloney, \& Wilsey, 2005), African savannas (Kinyua, McGeoch, Georgiadis, \& Young, 2010) and Australian savannas (O'Dwyer \& Attiwill, 2000). There is evidence that it is possible to reintroduce many native species of trees and some shrubs and herbs in the Brazilian savanna through direct seeding (Pellizzaro et al., 2017; Silva \& Vieira, 2017). However, the present study shows that there are major challenges to establishing an initial community resistant to re-establishment of invasive grasses. Our results showed that competition was asymmetric, with invasive species gaining more space than native species. Invasive grasses were able to maintain dominance in plots where their initial percent cover was above $80 \%$ and increase percent cover in other plots, completely outcompeting native species in some plots. On the other hand, more than $80 \%$ of cover of native species was insufficient to prevent invasive grasses from spreading. Here, as in other grassland ecosystems around the world, asymmetric competition has been observed between invasive grasses and native species (Bakker \& Wilson, 2001; Schwinning, Meckel, Reichmann, Polley, \& Fay, 2017).

Invasive grasses can outcompete native species through resource preemption or non-resource-mediated effects, such as allelopathy (Barbosa, Pivello, \& Meirelles, 2008; Kato-Noguchi et al., 2014). Urochloa decumbens and Andropogon gayanus were the most aggressive invasive species in our study plots. Urochloa decumbens was introduced in Brazil as livestock forage (Lorenzi, 1991; Parsons, 1972) and became a strong invader in Brazilian savannas (Pivello et al., 1999). Urochloa decumbens has allelopathic properties capable of displacing Melinis minutiflora, another strongly invasive grass in the Americas (D'Antonio, Yelenik, \& Mack, 2017; Pivello et al., 1999). In fertilized areas, Urochloa decumbens has high productivity when $\mathrm{P}$ and $\mathrm{K}$ are provided, resulting in high leaf biomass (Rao, Kerridge, \& Macedo, 1996). However, it is also well adapted to the acid and nutrient-poor cerrado soils, which are low in $\mathrm{P}$ and $\mathrm{Ca}$ but have high levels of Al (Rao et al., 1996). Native tree species of Australian (Sun \& Dickson, 1996) and Brazilian savannas (Pereira, Laura, \& Souza, 2013) germinate and grow better in the absence of Urochloa spp., suggesting that these invasive grasses strongly compete for nutrients and water belowground. Andropogon gayanus was also introduced 
FIGURE 5 Sankey diagram showing shifts in functional-group dominance between 2015 and 2017 in savanna restoration sites in Chapada dos Veadeiros National Park, central Brazil. The node width represents the number of plots [Color figure can be viewed at wileyonlinelibrary.com]

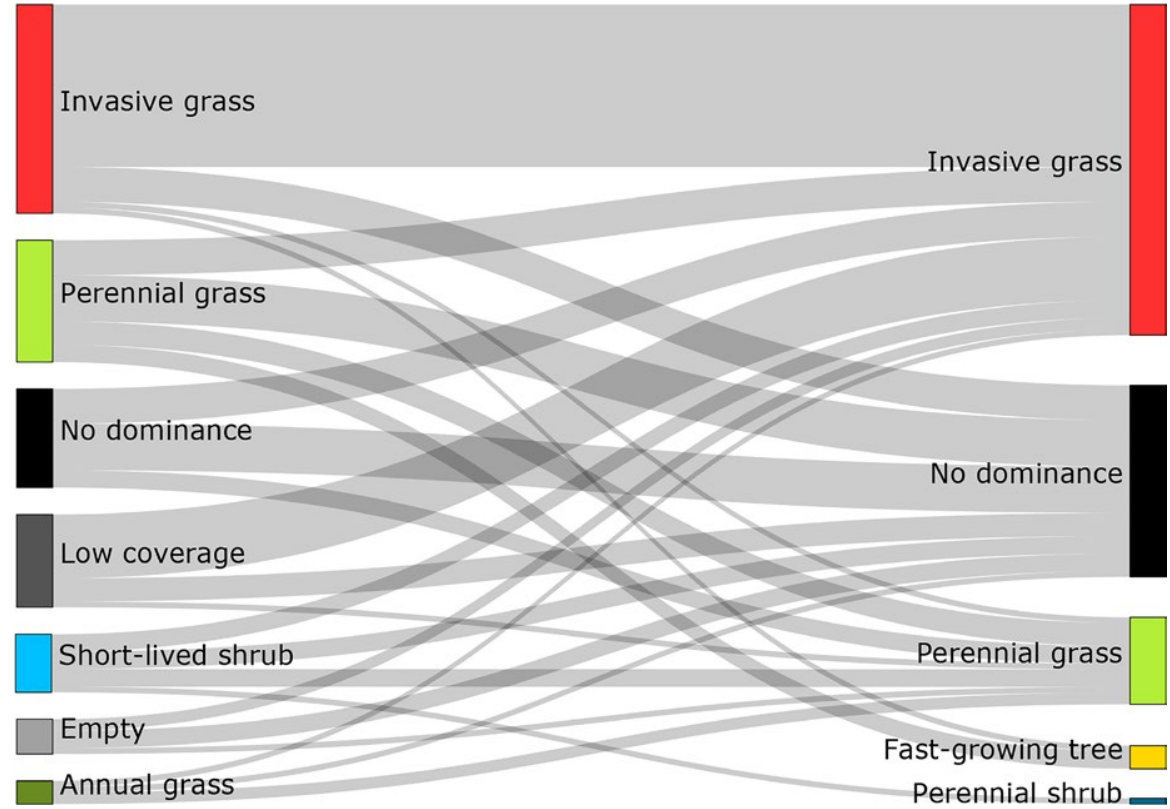

intentionally to be used as forage (Boddey et al., 2004) and became an invasive grass with a high dispersal ability; a single tussock can produce about 12,000 caryopses in a year (Bowden, 1964). These traits give these species competitive advantage, allowing them to invade and be successful in plots where they were absent before.

Our results demonstrated a successional trajectory in the restored area, with rapid species turnover. As far as we know, secondary succession has not been described in severely disturbed savannas where seed and bud banks had been extinguished. This study used a limited pool of species, but it is pertinent to understand community succession, which is useful for designing restoration methods for savannas. Two short-lived shrubs, Lepidaploa aurea and Stylosanthes spp., and one annual native grass, Andropogon fastigiatus, rapidly covered the ground at the early restoration stages, but they died two to three years after sowing, leaving empty spaces for colonization or expansion of perennial species. These short-lived species are commonly found colonizing and establishing in bare soil sites, such as roadsides and mining areas (A. G. Coutinho \& D. L. M. Vieira, pers. obs.) and are rarely found in mature savanna sites (Silva, Amaral, Bijos, \& Munhoz, 2018). Native and invasive perennial grasses were able to occupy the available space. In a few more years, the native tree species will grow and their canopy cover should increase and achieve $5 \%-20 \%$ cover, which is typical of open savannas (Ribeiro \& Walter, 2008).

The herbaceous layer of tropical savannas is usually dominated by perennial grasses, and other life forms are less predominant (Sarmiento, 1992). However, in our study, annual and short-lived plants were important to rapidly cover the ground, preventing soil erosion and modifying microclimate and soil structure while perennial grasses and trees slowly grow. The presence of these functional groups at the beginning of the study did not prevent the establishment of invasive or perennial native grasses, which achieved higher cover in plots with initial presence of annual and short-lived species.
Stylosanthes spp. subshrubs are used as forage in planted pastures (Miles \& Lascano, 1997; Phengsavanh \& Ledin, 2003) and may increase soil fertility, which may have contributed to their inefficiency in excluding invasive grasses. In another experiment in the same restoration area, Stylosanthes capitata and Stylosanthes macrocephala did not exclude invasive grasses, even when sown in high densities (Alves, 2016). Stylosanthes spp. did successfully prevent the establishment of invasive grasses during the restoration of a gravel mine in a Brazilian savanna (Starr, Corrêa, Filgueiras, Hay, \& dos Santos, 2013), but in this case, the soil had been eliminated by the mining activity, which created harsh conditions for the establishment of invasive grasses. The dense seed bank of invasive grasses in our study areas may have hindered the preventive effects of Andropogon fastigiatus and Lepidaploa aurea. Andropogon fastigiatus is considered a "pasture invader", sometimes even displacing invasive grasses (Lorenzi, 1991). Lepidaploa aurea has allelopathic effects on Urochloa decumbens (Lopes, Caldas Oliveira, Salles, Sampaio, \& Schmidt, 2018).

Schizachyrium sanguineum and Tachigali vulgaris were the most successful native species in our experiment. Tachigali vulgaris is a fast-growing tree, and this ability allowed this species to overcome the grass cover. All other 21 seeded trees had good establishment, but a very slow growth rate (Pellizzaro et al., 2017; Silva \& Vieira, 2017). Not only did Schizachyrium sanguineum occupy the spaces left by the short life-cycle species, but it was also able to invade plots dominated by invasive grasses. It is likely that Schizachyrium sanguineum is more functionally similar to invasive grasses than the other species, which would allow this species to compete with them (Funk et al., 2008).

Invasive grasses may present a difficult challenge if not completely eliminated prior to sowing and/or constantly controlled. The combination of fire and plowing may be an effective method to remove them (Durigan, Guerin, \& Neves da Costa, 2013), but this 
treatment may need to be applied several times and/or for years. One alternative for depleting the seed bank of invasive species is to stimulate germination (Carmona, 1992), which can be done through successive plowing operations in the same area. More drastically, topsoil removal can completely eliminate the seed bank (Kiehl, Kirmer, Donath, Rasran, \& Hölzel, 2010). Herbicides are an effective method that can be applied at a large scale (Ansley \& Castellano, 2006; Bakker et al., 2003; Durigan et al., 2013), but may not be permitted in protected areas. Our study highlights that, in non-resilient savanna restoration, community assembly can follow a successional pathway when short-lived and perennial species are sown. Although old-growth savannas and grasslands are characterized by slow growth of woody plants and an apparent slow succession of plant species, our results showed that, during the initial restorations stages, species turnover can happen rapidly. This should be taken into consideration when developing restoration strategies in these environments. From the first stages of restoration, it is important to introduce species that will assume different roles in early successional stages. Fast-growing species prevent soil erosion and modify microhabitat conditions, perennial grasses re-establish the grass-layer, and trees and perennial shrubs contribute for savanna structure later in the restoration trajectory.

\section{ACKNOWLEDGEMENTS}

We are grateful to the Plant Ecology Laboratory at the Ecology Department of University of Brasília for assistance in field measurements. Professors Giselda Durigan and Mercedes Bustamante provided helpful advice on an early version of this manuscript. Beatriz Baker conducted a careful English review. A.G. Coutinho received an M.S. fellowship from CNPq.

\section{ORCID}

Isabel Belloni Schmidt (iD https://orcid.org/0000-0001-9420-6509

Daniel Luis Mascia Vieira (iD https://orcid.org/0000-0002-2709-5308

\section{REFERENCES}

Almeida-Neto, M., Prado, P. I., Kubota, U., Bariani, J. M., Aguirre, G. H., \& Lewinsohn, T. M. (2010). Invasive grasses and native Asteraceae in the Brazilian Cerrado. Plant Ecology, 209(1), 109-122. https://doi. org/10.1007/s11258-010-9727-8

Alves, M. (2016). Semeadura direta de ervas, arbustos e árvores para restauração do Cerrado. Master thesis in Ecology, University of Brasília, Brazil.

Ansley, R. J., \& Castellano, M. J. (2006). Strategies for savanna restoration in the Southern Great Plains: effects of fire and herbicides. Restoration Ecology, 14(3), 420-428. https://doi. org/10.1111/j.1526-100x.2006.00150.x

Baasch, A., Engst, K., Schmiede, R., May, K., \& Tischew, S. (2016). Enhancing success in grassland restoration by adding regionally propagated target species. Ecological Engineering, 94, 583-591. https://doi.org/10.1016/j.ecoleng.2016.06.062
Bakker, J., \& Wilson, S. (2001). Competitive abilities of introduced and native grasses. Plant Ecology, 157(2), 119-127. https://doi. org/10.1023/a:1013972403293

Bakker, J. D., Wilson, S. D., Christian, J. M., Li, X., Ambrose, L. G., \& Waddington, J. (2003). Contingency of grassland restoration on year, site, and competition from introduced grasses. Ecological Applications, 13(1), 137-153. https://doi. org/10.1890/1051-0761(2003)013[0137:COGROY]2.0.CO;2

Barbosa, E. G., Pivello, V. R., \& Meirelles, S. T. (2008). Allelopathic evidence in Brachiaria decumbens and its potential to invade the Brazilian Cerrados. Brazilian Archives of Biology and Technology, 51(4), 825-831. https://doi.org/10.1590/s1516-89132008000400021

Baruch, Z. (1996). Ecophysiological aspects of the invasion by African grasses and their impact on biodiversity and function of neotropical savannas. In O. T. Solbrig, E. Medina, \& J. F. Silva (Eds.), Biodiversity and Savanna ecosystem processes (pp. 79-93). Berlin, Germany: Springer. https://doi.org/10.1007/978-3-642-78969-4_5

Baruch, Z., Hernández, A. B., \& Montilla, M. G. (1989). Dinámica del crecimiento, fenología y repartición de biomasa en gramíneas nativas e introducidas de una sabana Neotropical. Ecotropicos, 2, 1-13.

Berger, W. H., \& Parker, F. L. (1970). Diversity of planktonic foraminifera in deep-sea sediments. Science, 168(3937), 1345-1347. https://doi. org/10.1126/science.168.3937.1345

Boddey, R. M., Macedo, R., Tarré, R. M., Ferreira, E., de Oliveira, O. C., Rezende, C. de P., ... Urquiaga, S. (2004). Nitrogen cycling in Brachiaria pastures: the key to understanding the process of pasture decline. Agriculture, Ecosystems \& Environment, 103(2), 389-403. https://doi. org/10.1016/j.agee.2003.12.010

Bond, W. J., \& Keeley, J. E. (2005). Fire as a global 'herbivore': The ecology and evolution of flammable ecosystems. Trends in Ecology \& Evolution, 20(7), 387-394. https://doi.org/10.1016/j.tree.2005.04.025

Bond, W. J., \& Parr, C. L. (2010). Beyond the forest edge: Ecology, diversity and conservation of the grassy biomes. Biological Conservation, 143(10), 2395-2404. https://doi.org/10.1016/j.biocon.2009.12.012

Bowden, B. N. (1964). Studies on Andropogon gayanus Kunth: III. An outline of its biology. Journal of Ecology, 52(2), 255-271. https://doi. org/10.2307/2257594

Campos-Filho, E. M., Da Costa, J. N. M. N., De Sousa, O. L., \& Junqueira, R. G. P. (2013). Mechanized direct-seeding of native forests in Xingu, central Brazil. Journal of Sustainable Forestry, 32(7), 702-727. https:// doi.org/10.1080/10549811.2013.817341

Carmona, R. (1992). Problemática e manejo de bancos de sementes de invasoras em solos agrícolas. Planta Daninha, 10(1-2), 05-16. https:// doi.org/10.1590/s0100-83581992000100007

Cava, M. G. B., Pilon, N. A. L., Ribeiro, M. C., \& Durigan, G. (2017). Abandoned pastures cannot spontaneously recover the attributes of old-growth savannas. Journal of Applied Ecology, 55(3), 1164-1172. https://doi.org/10.1111/1365-2664.13046

Clewell, A. F., \& Aronson, J. (2007). Ecological restoration - Principles, values, and structure of an emerging profession. Washington, DC: Island Press/Center for Resource Economics.

Coulloudon, B., Eshelman, K., Gianola, J., Habich, N., Hughes, L., Johnson, C.... Willoughby, J. (1999). Sampling vegetation attributes: Interagency technical reference. Denver, CO: U.S. Department of the Interior, Bureau of Land Management-National Applied Resources Science Center.

D'Antonio, C. M., \& Vitousek, P. M. (1992). Biological invasions by exotic grasses, the grass/fire cycle, and global change. Annual Review of Ecology and Systematics, 23, 63-87. https://doi.org/10.1146/annurev. es.23.110192.000431

D'Antonio, C. M., Yelenik, S. G., \& Mack, M. C. (2017). Ecosystem vs. community recovery 25 years after grass invasions and fire in a subtropical woodland. Journal of Ecology, 105(6), 1462-1474. https://doi. org/10.1111/1365-2745.12855

Davidson, A. M., Jennions, M., \& Nicotra, A. B. (2011). Do invasive species show higher phenotypic plasticity than native species and if 
so, is it adaptive? A meta-analysis. Ecology Letters, 14(4), 419-431. https://doi.org/10.1111/j.1461-0248.2011.01596.x

Durigan, G., Guerin, N., \& Neves da Costa, J. N. M. (2013). Ecological restoration of Xingu Basin headwaters: motivations, engagement, challenges and perspectives. Philosophical Transactions of the Royal Society B: Biological Sciences, 368(1619), 20120165. https://doi. org/10.1098/rstb.2012.0165

Ferreira, M. C., Walter, B. M. T., \& Vieira, D. L. M. (2015). Topsoil translocation for Brazilian savanna restoration: oropagation of herbs, shrubs, and trees. Restoration Ecology, 23(6), 723-728. https://doi. org/10.1111/rec.12252

Firn, J., House, A. P. N., \& Buckley, Y. M. (2010). Alternative states models provide an effective framework for invasive species control and restoration of native communities. Journal of Applied Ecology, 47(1), 96-105. https://doi.org/10.1111/j.1365-2664.2009.01741.x

Fort, F., Cruz, P., \& Jouany, C. (2014). Hierarchy of root functional trait values and plasticity drive early-stage competition for water and phosphorus among grasses. Functional Ecology, 28(4), 1030-1040. https://doi.org/10.1111/1365-2435.12217

Foxcroft, L. C., Richardson, D. M., Rejmánek, M., \& Pyšek, P. (2010). Alien plant invasions in tropical and sub-tropical savannas: patterns, processes and prospects. Biological Invasions, 12(12), 3913-3933. https://doi.org/10.1007/s10530-010-9823-7

Fukami, T. (2015). Historical contingency in community assembly: Integrating niches, species pools, and priority effects. Annual Review of Ecology, Evolution, and Systematics, 46(1), 1-23. https://doi. org/10.1146/annurev-ecolsys-110411-160340

Funk, J. L., Cleland, E. E., Suding, K. N., \& Zavaleta, E. S. (2008). Restoration through reassembly: plant traits and invasion resistance. Trends in Ecology \& Evolution, 23(12), 695-703. https://doi. org/10.1016/j.tree.2008.07.013

González, E., Rochefort, L., Boudreau, S., Hugron, S., \& Poulin, M. (2013). Can indicator species predict restoration outcomes early in the monitoring process? A case study with peatlands. Ecological Indicators, 32, 232-238. https://doi.org/10.1016/j.ecolind.2013.03.019

Grossnickle, S. C., \& Ivetić, V. (2017). Direct seeding in reforestation - a field performance review. Reforesta, 4, 94-142. https://doi. org/10.21750/refor.4.07.46

Hedberg, P., \& Kotowski, W. (2010). New nature by sowing? The current state of species introduction in grassland restoration, and the road ahead. Journal for Nature Conservation, 18(4), 304-308. https://doi. org/10.1016/j.jnc.2010.01.003

Hoffmann, W. A., Geiger, E. L., Gotsch, S. G., Rossatto, D. R., Silva, L. C. R., Lau, O. L., Haradasan, M., Franco, A. C. (2012). Ecological thresholds at the savanna-forest boundary: how plant traits, resources and fire govern the distribution of tropical biomes. Ecology Letters, 15(7), 759-768. https://doi.org/10.1111/j.1461-0248.2012.01789.x

Holl, K. D., Howard, E. A., Brown, T. M., Chan, R. G., de Silva, T. S., Mann, E. T., ... Spangler, W. H. (2014). Efficacy of exotic control strategies for restoring coastal prairie grasses. Invasive Plant Science and Management, 7(4), 590-598. https://doi.org/10.1614/ ipsm-d-14-00031.1

ICMBio (2009). Plano de Manejo Parque Nacional Chapada dos Veadeiros. Encarte I e II. Brasília, Brazil: ICMBio

Jacobs, B. F., Kingston, J. D., \& Jacobs, L. L. (1999). The origin of grassdominated ecosystems. Annals of the Missouri Botanical Garden, 86(2), 590-643. https://doi.org/10.2307/2666186

Jonasson, S. (1988). Evaluation of the point intercept method for the estimation of plant biomass. Oikos, 52, 101-106. https://doi. org/10.2307/3565988

Kato-Noguchi, H., Kobayashi, A., Ohno, O., Kimura, F., Fujii, Y., \& Suenaga, K. (2014). Phytotoxic substances with allelopathic activity may be central to the strong invasive potential of Brachiaria brizantha. Journal of Plant Physiology, 171(7), 525-530. https://doi. org/10.1016/j.jplph.2013.11.010
Kiehl, K., Kirmer, A., Donath, T. W., Rasran, L., \& Hölzel, N. (2010). Species introduction in restoration projects - Evaluation of different techniques for the establishment of semi-natural grasslands in Central and Northwestern Europe. Basic and Applied Ecology, 11(4), 285-299. https://doi.org/10.1016/j.baae.2009.12.004

Kinyua, D., McGeoch, L. E., Georgiadis, N., \& Young, T. P. (2010). Shortterm and long-term effects of soil ripping, seeding, and fertilization on the restoration of a tropical rangeland. Restoration Ecology, 18(s1), 226-233. https://doi.org/10.1111/j.1526-100x.2009.00594.x

Kunstler, G., Falster, D., Coomes, D. A., Hui, F., Kooyman, R. M., Laughlin, D. C., ... Westoby, M. (2016). Plant functional traits have globally consistent effects on competition. Nature, 529(7585), 204-207. https:// doi.org/10.1038/nature16476

Lawes, M. J., Adie, H., Russell-Smith, J., Murphy, B., \& Midgley, J. J. (2011). How do small savanna trees avoid stem mortality by fire? The roles of stem diameter, height and bark thickness. Ecosphere, 2(4), 42. https://doi.org/10.1890/es10-00204.1

Lehmann, C. E. R., Archibald, S. A., Hoffmann, W. A., \& Bond, W. J. (2011). Deciphering the distribution of the savanna biome. New Phytologist, 191(1), 197-209. https://doi.org/10.1111/j.1469-8137.2011.03689.x

Lopes, P. G., Caldas Oliveira, S. C., Salles, K. A., Sampaio, A. B., \& Schmidt, I. B. (2018). Allelopathy of a native shrub can help control invasive grasses at sites under ecological restoration in a Neotropical savanna. Plant Ecology \& Diversity, 1-12. https://doi.org/10.1080/175 50874.2018.1539132

Lorenzi, H. (1991). Plantas Daninhas do Brasil, 2nd ed.. Nova Odessa, Brazil: Instituto Plantarum.

Martin, L. M., Moloney, K. A., \& Wilsey, B. J. (2005). An assessment of grassland restoration success using species diversity components. Journal of Applied Ecology, 42(2), 327-336. https://doi. org/10.1111/j.1365-2664.2005.01019.x

Miles, J. W., \& Lascano, C. E. (1997). Status of Stylosanthes development in other countries. I. Stylosanthes development and utilization in South America. Tropical Grasslands, 31, 454-459.

O'Dwyer, C., \& Attiwill, P. M. (2000). Restoration of a native grassland as habitat for the golden sun moth Synemon plana Walker (Lepidoptera; Castniidae) at Mount Piper, Australia. Restoration Ecology, 8(2), 170174. https://doi.org/10.1046/j.1526-100x.2000.80024.x

Oksanen, J., Blanchet, F. G., Friendly, M., Kindt, R., Legendre, P., McGlinn, D., ... Wagner, H. (2018). Vegan: Community ecology package. $R$ package version version 2.5-2. Retrieved from http://cran.r-project.org/, http://vegan.rforge.r-project.org/

Palma, A. C., \& Laurance, S. G. W. (2015). A review of the use of direct seeding and seedling plantings in restoration: what do we know and where should we go? Applied Vegetation Science, 18(4), 561-568. https://doi.org/10.1111/avsc.12173

Parsons, J. J. (1972). Spread of African pasture grasses to the American tropics. Journal of Range Management, 25(1), 12-17. https://doi. $\operatorname{org} / 10.2307 / 3896654$

Pellizzaro, K. F., Cordeiro, A. O. O., Alves, M., Motta, C. P., Rezende, G. M., Silva, R. R. P., ... Schmidt, I. B. (2017). "Cerrado" restoration by direct seeding: field establishment and initial growth of 75 trees, shrubs and grass species. Brazilian Journal of Botany, 40(3), 681-693. https://doi.org/10.1007/s40415-017-0371-6

Pereira, S. R., Laura, V. A., \& Souza, A. L. T. (2013). Establishment of Fabaceae tree species in a tropical pasture: influence of seed size and weeding methods. Restoration Ecology, 21(1), 67-74. https://doi. org/10.1111/j.1526-100x.2011.00858.x

Phengsavanh, P., \& Ledin, I. (2003). Effect of Stylos 184 (Stylosanthes guianensis CIAT 184) and Gamba grass (Andropogon gayanus cv. Kent) in diets for growing goats. Livestock Research for Rural Development, 15(10), 71.

Pilon, N. A., Buisson, E., \& Durigan, G. (2017). Restoring Brazilian savanna ground layer vegetation by topsoil and hay transfer. Restoration Ecology, 26(1), 73-81. https://doi.org/10.1111/rec.12534 
Pivello, V. R., Shida, C. N., \& Meirelles, S. T. (1999). Alien grasses in Brazilian savannas: a threat to the biodiversity. Biodiversity \& Conservation, 8(9), 1281-1294. https://doi.org/10.1023/a:1008933305857

Poos, M. S., \& Jackson, D. A. (2012). Addressing the removal of rare species in multivariate bioassessments: The impact of methodological choices. Ecological Indicators, 18, 82-90. https://doi.org/10.1016/j. ecolind.2011.10.008

Pywell, R. F., Bullock, J. M., Roy, D. B., Warman, L. I. Z., Walker, K. J., \& Rothery, P. (2003). Plant traits as predictors of performance in ecological restoration. Journal of Applied Ecology, 40(1), 65-77. https:// doi.org/10.1046/j.1365-2664.2003.00762.x

R Core Team (2017) R: A Language and Environment for Statistical Computing. Vienna, Austria: R Foundation for Statistical Computing. https://www.R-project.org/

Rao, I. M., Kerridge, P. C., \& Macedo, M. C. M. (1996). Nutritional requirements of Brachiaria and adaptation to acid soils. In J. W.Miles, B. L.Maass, C. Borges do Valle, \& V. Kumble (Eds.). Brachiaria: Biology, agronomy, and improvement (pp. Centro Internacional de Agricultura Tropical (CIAT).Empresa Brasileira de Pesquisa Agropecuaria (EMBRAPA), Centro Nacional de Pesquisa de Gado de Corte (CNPGC), Campo Grande, Brazil.

Ribeiro, J. F., \& Walter, B. M. (2008). As principais fitofisionomias do bioma Cerrado. In S. M. Sano, S. P. Almeida, \& J. F. Ribeiro (Eds.), Cerrado: Ecologia e flora, 2nd ed. (pp. 151-212). Brasília, Brazil: Embrapa Informação Tecnológica.

Sarmiento, G. (1992). Adaptive strategies of perennial grasses in south american savannas. Journal of Vegetation Science, 3(3), 325-336. https://doi.org/10.2307/3235757

Schwinning, S., Meckel, H., Reichmann, L. G., Polley, H. W., \& Fay, P. A. (2017). Accelerated development in Johnsongrass seedlings (Sorghum halepense) suppresses the growth of native grasses through size-asymmetric competition. PLoS One, 12(5), e0176042. https:// doi.org/10.1371/journal.pone.0176042

Silva, D. P. D., Amaral, A. G., Bijos, N. R., \& Munhoz, C. B. R. (2018). Is the herb-shrub composition of veredas (Brazilian palm swamps) distinguishable? Acta Botanica Brasilica, 32(1), 47-54.

Silva, R. R. P., Oliveira, D. R., da Rocha, G. P. E., \& Vieira, D. L. M. (2015). Direct seeding of Brazilian savanna trees: effects of plant cover and fertilization on seedling establishment and growth. Restoration Ecology, 23(4), 393-401. https://doi.org/10.1111/rec.12213

Silva, R. R. P., \& Vieira, D. L. M. (2017). Direct seeding of 16 Brazilian savanna trees: responses to seed burial, mulching and an invasive grass. Applied Vegetation Science, 20(3), 410-421. https://doi.org/10.1111/ avsc. 12305

Simon, M. F., Grether, R., de Queiroz, L. P., Skema, C., Pennington, R. T., \& Hughes, C. E. (2009). Recent assembly of the Cerrado, a neotropical plant diversity hotspot, by in situ evolution of adaptations to fire. Proceedings of the National Academy of Sciences oof the United States of America, 106(48), 20359-20364. https://doi.org/10.1073/ pnas.0903410106

Souchie, F. F., Pinto, J. R. R., Lenza, E., Gomes, L., Maracahipes-Santos, L., Silvério, D. V., ... Silvério, D. V. (2017). Post-fire resprouting strategies of woody vegetation in the Brazilian savanna. Acta Botanica Brasilica, 31(2), 260-266. https://doi.org/10.1590/0102-33062016abb0376

Starr, C. R., Corrêa, R. S., Filgueiras, T. de. S., Hay, J. D. V., \& dos Santos, P. F. (2013). Plant colonization in a gravel mine revegetated with Stylosanthes spp in a Neotropical savanna. Landscape and Ecological Engineering, 9(1), 189-201. https://doi.org/10.1007/ s11355-012-0196-1

Suding, K. N. (2011). Toward an era of restoration in ecology: Successes, failures, and opportunities ahead. Annual Review of Ecology Evolution, and Systematics, 42, 465-487. https://doi.org/10.1146/ annurev-ecolsys-102710-145115

Suding, K. N., \& Hobbs, R. J. (2009). Threshold models in restoration and conservation: a developing framework. Trends in Ecology \& Evolution, 24(5), 271-279. https://doi.org/10.1016/j.tree.2008.11.012

Sun, D., \& Dickson, G. R. (1996). The competition effect of Brachiaria decumbens on the early growth of direct-seeded trees of Alphitonia petriei in tropical north Australia. Biotropica, 28(2), 272-276. https:// doi.org/10.2307/2389082

Vaughn, K. J., \& Young, T. P. (2015). Short-term priority over exotic annuals increases the initial density and longer-term cover of native perennial grasses. Ecological Applications, 25(3), 791-799.

Veldman, J. W., Buisson, E., Durigan, G., Fernandes, G. W., Le Stradic, S., Mahy, G., ... Bond, W. J. (2015). Toward an old-growth concept for grasslands, savannas, and woodlands. Frontiers in Ecology and the Environment, 13(3), 154-162. https://doi.org/10.1890/140270

Vilà, M., \& Weiner, J. (2004). Are invasive plant species better competitors than native plant species? - evidence from pair-wise experiments. Oikos, 105(2), 229-238.https://doi. org/10.1111/j.0030-1299.2004.12682.x

Werner, C. M., Vaughn, K. J., Stuble, K. L., Wolf, K., \& Young, T. P. (2016). Persistent asymmetrical priority effects in a California grassland restoration experiment. Ecological Applications, 26(6), 1624-1632. https://doi.org/10.1890/15-1918.1

Wortley, L., Hero, J.-M., \& Howes, M. (2013). Evaluating ecological restoration success: a review of the literature. Restoration Ecology, 21(5), 537-543. https://doi.org/10.1111/rec.12028

Young, T. P., Zefferman, E. P., Vaughn, K. J., \& Fick, S. (2014). Initial success of native grasses is contingent on multiple interactions among exotic grass competition, temporal priority, rainfall and site effects. AoB Plants, 7, plu081, 1-9. https://doi.org/10.1093/aobpla/plu081

\section{SUPPORTING INFORMATION}

Additional supporting information may be found online in the Supporting Information section at the end of the article.

Appendix S1 Sowed species in the restoration area.

Appendix S2 Sampled species in the restoration area.

How to cite this article: Coutinho AG, Alves M, Sampaio AB, Schmidt IB, Vieira DLM. Effects of initial functional-group composition on assembly trajectory in savanna restoration. Appl Veg Sci. 2019;22:61-70. https://doi.org/10.1111/ avsc. 12420 